Prevention in Atlanta, Georgia, have been helping countries in the Middle East to boost surveillance. During the annual hajj religious pilgrimage in Saudi Arabia in late October, when millions of people visited the country before returning home - a potential recipe for global virus spread - both Saudi Arabia and return countries were on high alert.

Beyond immediate surveillance efforts, increased monitoring for coronavirus antibodies in the wider population should help to pin down the true death rate. The current high death rate would fall, for example, if many people in the vicinity of cases turn out to have antibodies to the virus but have not developed serious disease.

Meanwhile, laboratory studies are shedding light on the virus itself. This week, a team including Drosten has shown that this coronavirus seems to differ from the SARS virus in some important ways ${ }^{3}$. Because the SARS virus binds to the ACE-2 receptor on human cells deep in the lungs, it causes serious disease in the lower respiratory tract but is relatively difficult to contract and is not easily spread by coughing or sneezing. The researchers have determined that the new coronavirus does not bind to the ACE-2 receptor, but declined to elaborate on which receptor it does use, pending a separate publication. But ruling out the ACE-2 receptor has immediate practical implications - all the reagents and therapeutic strategies developed for the SARS virus will be of little use with this latest virus, says Drosten.

The same team also found that cells from bats, pigs and humans can all be infected in the lab with the coronavirus. This suggests that it is "promiscuous among mammals", says Drosten, and that it might jump readily between mammal species, although he cautions against extrapolating such in vitro studies to the real world.

More clues have come from Ian Lipkin, a renowned 'virus hunter' from Columbia University in New York, who was invited by the Saudi government in October to study the first cases there. He told Nature that he has discovered that partial genetic sequences of a virus isolated from bats match the coronavirus found in humans. "The finding gives insight into the original source of the virus," he says.

The route taken by this coronavirus to infect humans is still not clear. It could, for example, be carried by intermediate animal hosts, or in foodstuffs contaminated by the faeces of bats or other infected animals. To answer that, says Lipkin, "one would need to work for months". He hopes to send in another team to work alongside his Saudi colleagues in the near future.

1. Corman, V. M. et al. Euro Surveill. 17, 39 (2012).

2. Corman, V. M. et al. Euro Surveill. 17, 49 (2012).

3. Müller, M. A. et al. mBio 3, e00515-12 (2012).

COMMUNITY

\title{
NIH tackles major workforce issues
}

\section{US agency aims to expand training options for graduate students and to increase demographic diversity.}

\section{BY MEREDITH WADMAN}

$\mathrm{T}$ The world's largest biomedical research funding agency last week announced a programme of nudges, incentives and requirements intended to respond to two thorny workforce-related problems: the oversupply of young scientists who face diminishing prospects of landing academic jobs, and the lack of demographic diversity in the US biomedical workforce.

Two reports issued in June challenged the US National Institutes of Health (NIH) to better prepare young biologists for an evolving and increasingly competitive job market, and to boost diversity (see Nature 486, 304; 2012). In response, the agency, based in Bethesda, Maryland, will spend an average of US $\$ 50$ million a year for 10 years on a grant programme designed to provide financial support and mentoring to undergraduates at less-researchintensive institutions, which tend to have more diverse student populations. Another set of up to 50 grants, each worth about $\$ 250,000$, will entice institutions to launch innovative training programmes that prepare students for careers outside academia, in everything from science policy to industry and research administration. The agency will also encourage universities and other institutions to limit NIH-supported doctoral studies to five years.

To measure the success of the new initiatives, the NIH will require universities and academic medical centres to track the careers of all of their NIH-funded graduate students and postdocs for 15 years after they are trained. "The challenges facing the biomedical workforce are complex and these proposed initiatives are designed to effect real change," says Francis Collins, director of the NIH. "I'm optimistic that the entire scientific-research community will come together to help implement them."

The National Medical Association (NMA) in Silver Spring, Maryland, the main group representing black medical scientists, praised the agency's diversity plans, which also include a nationwide mentoring consortium, training on diversity issues for NIH review staff and members of peer-review panels, and a pilot scheme to assess anonymized grant applications. These initiatives were spurred by a study showing that, when other factors such as education are controlled for, black applicants are 10\% less likely than whites to win NIH grant funding (D. K. Ginther et al. Science 333, 1015-1019; 2011). Rahn Bailey, president of the NMA, called the plans "a move in the right direction".

But Shirley Tilghman, who co-chaired the working group that wrote the June workforce report, said that simply encouraging institutions to limit the length of doctoral studies isn't enough. Tilgh-

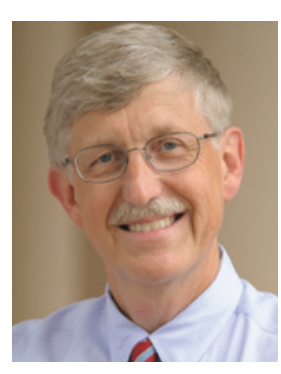

"These proposed initiatives are designed to effect real change." Francis Collins man, a molecular biologist and the president of Princeton University in New Jersey, told Collins's advisory committee on 6 December that "unless you get a stick, this won't happen". Her group's report noted that the number of US PhD biomedical graduates who secure tenure-track or tenured jobs has fallen from 34\% in 1993 to $26 \%$ today. She said that unless the NIH takes tougher steps, "we will be looking at data that look just like this ten more years from now".

Neither the June report nor the NIH response answer one key question - how many biomedical PhDs the United States should be training - because the necessary data and workforcemodelling expertise were not available either to the report's authors or to NIH staff. Indeed, the NIH also plans to hire at least one labour economist, to work as part of a new unit devoted to modelling biomedical-workforce needs.

As part of its workforce initiative, the NIH will increase yearly stipends for the 35,000 postdocs it supports from $\$ 39,000$ to $\$ 42,000$, a $7.7 \%$ rise, in an effort to reflect postdocs extensive training and to discourage lab heads from prolonging the postdoctoral training period. The National Postdoctoral Association in Washington DC applauded the NIH's plans. "The NIH has really stepped up to the plate in regard to early-career scientists," says Cathee Johnson Phillips, the group's executive director. The last time NIH-funded postdocs got a significant pay rise was in 2003 . 